\title{
ANALISIS BUDAYA ORGANISASI PEMERINTAH DAERAH (PEMDA) DI ERA OTONOMI DAERAH
}

\author{
Gilang Pramudhietha \\ Program Studi Ilmu Komunikasi \\ Fakultas Komunikasi dan Informatika \\ Universitas Muhammadiyah Surakarta \\ Email : gpramudhietha@yahoo.co.id
}

\begin{abstract}
Organization is a forum cooperation of a group individuals to achieve a goal it has set the vision and mission of the organization. To achieve the desired results required a commitment and a good organizational culture so that it can have a positive impact for the members of the organization and also for the institution in question. Organizational culture is the glue between members, therefore, an organization must have a strong culture, and commitment in line with the collective confidence to improve its ability to compete globally. The purpose of this study was to determine and describe the organizational culture of the local government in regional autonomy. This study uses qualitative descriptive method using data analysis techniques model of Miles and Huberman. Data was obtained through interviews with five respondents who are employees in the public relations department of the Regional Secretariat Wonogiri. The results showed that organizational culture is a type of culture of the local government hierarchy which can not be separated from regulation, policy, law, and control of government agencies. Organizational culture in the public relations department is dynamic and the culture that appears is a work culture that requires employees to work in a professional manner.
\end{abstract}

Keywords: Organizational Culture, Cultural Hierarchy, PR, Dynamic

\section{ABSTRAK}

Organisasi merupakan wadah kerjasama dari sekumpulan individu untuk mencapai suatu tujuan yang telah ditetapkan bersama yang menjadi visi dan misi organisasi. Untuk mencapai hasil yang diinginkan diperlukan suatu komitmen dan budaya organisasi yang baik sehingga bisa memberikan dampak yang positif bagi anggota organisasi dan juga bagi instansi yang bersangkutan. Budaya organisasi merupakan perekat antar anggota, oleh sebab itu, sebuah organisasi harus memiliki budaya yang kuat, komitmen yang sejalan dan dengan keyakinan kolektif untuk meningkatkan kemampuan bersaing secara global. Tujuan penelitian ini adalah untuk mengetahui dan mendeskripsikan budaya organisasi Pemda di era otonomi daerah. Penelitian ini menggunakan metode deskriptif kualitatif dengan menggunakan teknik analisis data model Miles dan Huberman. Data diperoleh melalui wawancara dengan lima responden yang merupakan pegawai di bagian humas Setda Wonogiri. Hasil penelitian menunjukkan bahwa budaya organisasi Pemda merupakan tipe budaya hirarki yang mana tidak terlepas dari peraturan, kebijakan, Undang-Undang dan kontrol instansi pemerintahan. Budaya organisasi di bagian humas bersifat dinamis dan budaya yang tampak adalah budaya kerja yang mengharuskan pegawai bekerja secara professional.

Kata Kunci : Budaya Organisasi, Budaya Hirarki, Humas, Dinamis 


\section{A. PENDAHULUAN}

Tata informasi Indonesia adalah suatu masalah yang luas dan rumit, masalah ini menyangkut berbagai tingkat komunikasi, mulai dari komunikasi antarpersona (komunikasi kelompok, komunikasi publik, komunikasi organisasi/birokrasi) hingga komunikasi massa, kemudian juga menyangkut berbagai bidang komunikasi yakni komunikasi politik, komunikasi bisnis, komunikasi lintas budaya, komunikasi pembangunan, komunikasi pendidikan dan sebagainya.

Di era otonomi daerah ini, di mana sebuah masa transisi yang selalu berubahubah diperlukan sebuah komunikasi dua arah, pengembangan sistem komunikasi seharusnya menjadi tujuan utama bagi humas pemda. Dalam hal ini, humas pemerintah daerah (Pemda) di era otonomi daerah seharusnya tidak hanya sekedar menginformasikan kegiatankegiatan pemerintah kepada masyarakat ataupun membela dan menyembunyikan keburukan pemerintah dari kritik publik. Sebagai praktisi humas, harus bisa menjadi jembatan penghubung antara kepentingan pemerintah dan masayarakat untuk mencapai tujuan bersama. (Mulyana, 2001)

Komunikasi sangat penting dalam eksistensi organisasi dan berperan lebih banyak daripada sekedar melaksanakan rencana-rencana organisasi karena melaksanakan rencana organisasi tidak akan terlaksana dengan baik jika tidak dikomunikasikan dengan baik dan tepat. Sehingga komunikasi menjadi faktor yang utama dalam sebuah organisasi. Tanpa komunikasi, organisasi tidak dapat berjalan dengan baik dan dapat memunculkan berbagai permasalahan seperti informasi yang minim, birokrasi yang tidak terkontrol dan tidak sesuai dengan harapan organisasi.

Urusan komunikasi dan informasi menjadi lebih banyak diserahkan pada masyarakat sendiri, sedang pemerintah lebih menempatkan diri sebagai pembuat kebijakan, regulator dan fasilitator. Untuk meningkatkan komunikasi, humas juga membangun dan memelihara hubungan yang kooperatif dengan wakil-wakil komunitas, masyarakat, pegawai dan public interest group, juga dengan perwakilan dari media cetak dan elektronik. Reformasi mendorong terjadinya banyak perubahan dalam berbagai aspek kehidupan di Indonesia. Buah reformasi yang diperjuangkan sejak tahun 1998 antara lain, adanya keterbukaan informasi sebagai salah satu dimensi dari demokrasi.

Termasuk di dalamnya adalah tuntutan masyarakat akan adanya keterbukaan informasi mengenai aktivitas lembaga pemerintahan. Informasi publik yang semula menjadi kekuasaan pemerintah yang dikelola secara ketat oleh manajemen komunikasi pemegang kekuasaan, semakin pudar sejalan dengan eksistensi transparansi dan demokratisasi semua bidang kehidupan. (Susanto, dalam Suharyati dkk, 2012).

Dalam Pemerintahan Daerah ada kesepakatan yang pada dasarnya memberikan dorongan agar fungsi humas pemerintah dapat dioptimalisasi melalui revitalisasi fungsi humas dalam mengkomunikasikan kegiatan tugastugas pemerintah pembangunan dan pelayanan masyarakat serta interaksi dengan masyarakat. SKB (Surat Keputusan Bersama) Tiga Menteri ini mendukung peran dan fungsi humas selaku pelaksana Undang- Undang No. 14 Tahun 2008 tentang Keterbukaan Informasi Publik $(K I P)$, semakin mengukuhkan peran dan kewajiban pemerintah untuk membuka saluran komunikasi dengan publik.

Undang-undang yang terdiri dari 64 pasal ini pada intinya memberikan kewajiban kepada setiap badan publik untuk membuka akses bagi publik untuk mendapatkan informasi yang terkait dengan kepentingan publik. Namun, saat ini masih sedikit instansi yang memberikan informasi yang terbuka kepada publik. Humas dalam hal ini harus berperan aktif membangun bagaimana memberikan informasi yang terbuka dan terpercaya kepada publik 
melalui saluran komunikasi yang digunakan oleh Humas.

Organisasi merupakan wadah kerjasama dari sekumpulan orang untuk mencapai suatu tujuan yang telah ditetapkan. Untuk menghasilkan suatu kerja sama diperlukan suatu keyakinan, sikap, norma, nilai dan pola perilaku yang disepakati bersama yang disebut budaya perusahaan atau budaya organisasi. Kebudayaan terdiri dari pola yang eksplisit maupun implisit, sebuah perilaku tertentu yang dialihkan melalui simbol-simbol yang merupakan prestasi kelompok manusia termasuk peninggalan berbentuk artefak yang merupakan inti dari gagasan-gagasan tradisional yang dibuat dalam nilai-nilai yang mereka terima.Sistem kebudayaan dapat diketahui melalui produk atau tindakan yang dipandang sebagai keadaan yang berpengaruh terhadap tindakan mereka.

Reynecke dalam Liliweri (2014) mendefinisikan kebudayaan sebagai deposit pengetahuan, pengalaman, kepercayaan, nilai, sikap, makna, hierarki, agama, catatan tentang waktu, peranan, relasi tertentu, konsep universal, objek material dan pemilikan yang diakui oleh suatu kelompok individu yang kemudian diwariskan turun temurun.

Definisi tersebut menggambarkan semua aspek yang dipengaruhi oleh kebudayaan yang mengindikasikan bahwa kebudayaan adalah pandangan hidup yang dikembangkan dan dipertukarkan oleh kelompok tertentu. Bagi anggota yang baru maka mereka harus mempelajari kebudayaan karena budaya tersebut diwariskan oleh generasi sebelumnya. Budaya organisasi yang dianut oleh pemda cenderung menggunakan budaya birokrasi, yang membuat mereka merasa mampu melaksanakan otonomi daerah meskipun dengan minimnya partisipasi dari masyarakat.

Budaya organisasi seperti ini, menganut pendekatan dari atas ke bawah sehingga peran partisipasi belum dikelola secara optimal yang pada akhirnya membuat banyak kebijakan kurang dikomunikasikan dengan masyarakat. (Purworini dkk, 2014) Budaya organisasi di birokrat cenderung kaku dan vertikal dari bawah ke atas. Unsur senioritas yang kental membuat dinamika komunikasi kurang berjalan dengan dinamis. Pada kondisi dimana potensi level bawah lebih baik dari atasan, potensi ini kurang bisa dioptmimalkan karena faktor rasa sungkan "perkewuh" terhadap atasan. Maka tidak mengherankan jika potensi tersebut terpendam dan hanya mengikuti pola yang diterapkan oleh atasan.

Budaya organisasi adalah norma, nilainilai asumsi, kepercayaan, filsafat, kebiasaan organisasi dan isi budaya organisasi yang dikembangkan dalam waktu yang lama oleh pendiri, pimpinan dan anggota organisasi sehingga mempengaruhi pola pikir, sikap dan perilaku anggota dalam memproduksi produk, melayani konsumen dan mencapai tujuan organisasi (Wirawan, dalam Setiati, 2012).

Adanyastrukturorganisasiyang memiliki banyak badan dan letak yang berbedabeda membuat koordinasi dalam organisasi pemerintah memerlukan sistem komunikasi yang baik dan juga sistem birokrasi yang sulit karena mengacu pada hierarki membuat komunikasi perlu dioptimalkan. Komunikasi yang efektif dapat menjadi usaha yang baik dalam mengoptimalkan koordinasi dan hubungan antar badan dalam organisasi pemerintah.

Budaya menjadi perbincangan yang menarik dan penting dalam era global sekarang ini. Bukan sekedar mendalami apa itu budaya organisasi tetapi dalam mengadakan perubahan yang berkesinambungan, persaingan dan kemampuan bertahan terhadap lingkungan yang berubah-ubah. Budaya organisasi menjadi kunci penting dari perubahan yang akan memberikan pengaruh yang kuat bagi sisten kerja organisasi.

Menurut Schein, kecenderungan kultur organisasi di era global dapat dijelaskan dengan memahami "learning" sebagai dasar adaptasi manusia terhadap 
lingkungannya. Konsep ini berawal dari sifat dasar kultur, yaitu bahwa kultur merupakan suatu kekuatan yang stabil dan konservatif. Padahal dalam menghadapi lingkungan yang berubah-ubah adalah daya adaptasi dan fleksibilitas. Inilah yang disebut dengan learning culture (Schein dalam Kusdi, 2011).

Bushardt, Stephen dkk (2011) dengan judul penelitian Organizational Culture, Formal Reward Structure and Effective Strategy Implementation: A Conceptual Model menyatakan bahwa sebuah keputusan yang penting dalam proses perubahan adalah kecepatan dimana perubahan budaya diimplementasikan dan bergantung pada kepribadian pemimpin serta tingkat ancaman dari luar. Pekerjaan seorang manajer sulit dan menantang sehingga membutuhkan penyesuaian konstan dan terus menerus untuk memastikan keselarasan budaya dengan tujuan organisasi.

Budaya organisasi dapat bervariasi dari lemah sampai kuat tergantung pada sejauh mana itu diterima dan mempengaruhi perilaku individu. Demikian pula, sejauh mana budaya organisasi sama dan sebangun dengan struktur organisasi berkisar dari rendah ke tinggi. Makalah ini menyajikan model interaksi kedua variabel dan bagaimana interaksi mereka mungkin berdampak pada penerapan strategi yang efektif. Proposisi penelitian disajikan mengenai aspek statis dari model dan saran untuk berlatih manajer disajikan diambil dari aspek model dinamis.

Hilman, Haim dan Siam, Mohammed (2014) dengan judul The Influence of Organizational Structure and Organization Culture on the Organizational Performance of Higher Educational Institutions: The Moderating Role of Strategy Communication menyatakan bahwa struktur organisasi dan budaya organisasi secara signifikan terkait dengan kinerja lembaga pendidikan tinggi di Palestina. Hasil lebih lanjut dari peran moderator menunjukkan bahwa strategi komunikasi gagal memoderasi pengaruh baik struktur organisasi dan budaya organisasi terhadap kinerja organisasi.
Penelitian ini bertujuan untuk menguji peran moderasi komunikasi strategi pengaruh organisasi pelaksanaan strategi pada kinerja organisasi.Studi ini secara khusus menyelidiki bagaimana moderat komunikasi strategi pengaruh dimensi organisasi pelaksanaan strategi, yaitu struktur organisasi dan budaya organisasi terhadap kinerja organisasi dengan fokus khusus pada lembaga pendidikan tinggi di Palestina. Penelitian ini menerapkan model persamaan struktural, khususnya Partial Least Square dengan teknik analisis SmartPLS untuk analisis data.

Berpijak pada penelitian mengenai budaya, peneliti tertarik untuk mengangkat tema budaya organisasi Pemda khususnya di bagian humas Setda Wonogiri. Alasan peneliti memilih objek di Wonogiri karena banyak orang mengganggap bahwa Kota Wonogiri belum maju saat ini, padahal Wonogiri merupakan kota yang sukses seperti slogannya yakni "Wonogiri Sukses" dan terkenal di dunia dan diakui oleh UNESCO dengan diakuinya Gunung Sewu sebagai warisan dunia, Museum wayang kulit yang ada di kecamatan Wuryantoro, Museum Karst di Pracimantoro serta batik tulis khas Wonogiri telah diakui oleh Dunia. Hal ini menjadi bukti bahwa Wonogiri merupakan kota yang maju tidak kalah dengan daerah-daerah lain yang telah maju dan bekrembang, Wonogiri juga telah dikenal oleh dunia serta memiliki potensi wisata yang menarik meliputi wisata alam, budaya dan religious yang kental.

Kesuksesan sebuah kota atau daerah tidak terlepas dari campur tangan pemerintah daerah setempat. Sehingga peran Humas Pemda diharapkan dapat memberikan kontribusi dalam pembangunan di era otonomi daerah, Humas Pemda Wonogiri telah berusaha memberikan pelayanan kepada masyarakat sebagai bentuk partisipasi kepada public berupa informasi, berita dan layanan keluhan masyarakat. Peneliti memilih Humas Setda Wonogiri sebagai objek penelitian karena dibagian tersebut belum lama terjadi mutasi kepegawaian seperti 
pergantian Kepala Bagian, Sub bagian dan Staff Humas. Sehingga rumusan masalah dalam penelitian ini adalah Bagaimana budaya organisasi Pemda di Era Otonomi Daerah khususnya di bagian humas Setda Wonogiri?

\section{B. TINJAUAN PUSTAKA}

\section{Komunikasi Organisasi : Konsep Teoritis}

Komunikasi merupakan kegiatan transmisi informasi, ide-ide, sikap atau pernyataan emosional dari satu orang atau kelompok yang disampaikan kepihak lain, terutama melalui simbol-simbol tertentu (Ardianto, 2011).

Menurut McQuail dan Windahl komunikasi berkaitan erat dengan pengirim pesan, media saluran, pesan-pesan, penerima dan terjadi hubungan antara pengirim dan penerima yang menimbulkan efek tertentu atau hubungannya dengan komunikasi dan suatu hal dalam rangkaian penyampaian pesan-pesan. Komunikasi terjadi pada seseorang atau dari yang melakukan aksi, interaksi dan reaksi dari satu pihak kepada pihak lain (Ardianto, 2011).

Komunikasi adalah pernyataan diri yang efektif; pertukaran pesan-pesan yang tertulis atau pesan dalam percakapan bahkan pesan yang melalui imajinasi; pertukaran informasi atau hiburan dengan kata-kata melalui percakapan atau dengan mode lain; pengalihan informasi dari seseorang kepada orang lain; pertukaran makna antarpribadi dengan system symbol dan proses pengalihan pesan melalui saluran tertentu kepada orang lain dengan efek tertentu (Walhstrom dalam Liliweri, 2014).

Pendekatan secara objektif adalah bahwa sebuah organisasi merupakan sesuatu yang bersifst fisik dan konkret dan merupakan sebuah struktur dengan batas-batas yang pasti. Istilah "organisasi" mengisyaratkan bahwa sesuatu yang nyata merangkum orang-orang, hubunganhubungan dan tujuan-tujuan. Sehingga sebagian orang menyebut pendekatan ini sebagai pandangan yang menganggap organisasi sebagai wadah (container view of organizations).

Sedangkan pendekatan subjektif adalah memandang organisai sebagai kegiatan yang dilakukan orang-orang terdiri dari tindakan-tindakan, interaksi dan transaksi yang melibatkan orang-orang. Organisasi diciptakan dan dilakukan melaui kontak yang terus menerus berubah dan dilakukan oleh orang-orang antara yang satu dengan yang lainnya. Berdasarkan pandangan objektif, organisasi berarti struktur; berdasarkan pandangan subjektif, organisasi berarti proses.

Proses interaksi dan kerjasama yang perlahan-lahan terus berkembang sehingga terbentuklah sebuah wadah yang menjadi tempat orang-orang berkumpul disebut juga dengan organisasi. Organisasi juga merupakan kelompok yang mempunyai diferensiasi peranan, atau kelompok yang sepakat untuk memenuhi seperangkat norma-norma.

Unsur-unsur dasar yang membentuk suatu organisasi dapat disimpulkan menjadi lima kategori besar, yaitu :

1. Anggota organisasi. Sebuah organisasi terdapat orang-orang yang melakukan pekerjaan organisasi. Orang-orang yang membentuk organisasi terlibat dalam beberapa kegiatan primer (Bois dalam Pace dan Faules, 2010). Mereka terlibat dalam kegiatan-kegiatan "pemikiran" meliputi konsep-konsep, penggunaan bahasa, pemecahan masalah dan pembentukan gagasan.Mereka terlibat dalam kegiatan-kegiatan "perasaan" yang mencakup emosi, keinginan, dan aspek-aspek perilaku orang yang bukan aspek intelektual. Mereka terlibat dalam kegiatan-kegiatan "self-moving" yang mencakup kegiatan fisik yang besar maupun terbatas.

2. Pekerjaan dalam organisasi. Pekerjaan yang dilakukan oleh anggota organisasi terdiri dari tugas formal dan informal. Menurut Gibson, Ivancevich dan Donnelly dalam Pace dan Faules (2010:151) menyatakan bahwa Tugas- 
tugas tersebut menghasilkan produk dan memberikan pelayanan organisasi, ditandai dengan tiga dimensi universal : isi, keperluan dan konteks.

3. Praktik-praktik pengelolaan. Tujuan utama pegawai manajerial adalah menyelesaikan pekerjaan melalui usaha orang lainnya. Manajer memuat keputusan mengenai anggota organisasi lainnya, biasanya bawahan, menggunakan sumber daya yang diperlukan untuk melaksanakan pekerjaan mereka.Sebagian manajer membawahi para pekerja yang beroperasi dan sebagaian membawahi manajer-manajer lainnya.

4. Struktur organisasi. Tosi, Rizzo dan Carol (1990) menyatakan bahwa, struktur organisasi merujuk kepada hubunganhubungan antara tugas-tugas yang dilaksanakan oleh anggota organisasi. Sedangkan menurut Robbins (1989) struktur organisasi ditentukan oleh tiga variabel kunci yakni kompleksitas, formalitas dan sentralisasi (Pace dan Faules, 2010)

5. Pedoman organisasi. Pedoman organisasi adalah serangkaian pernyataan yang mempengaruhi, mengendalikan dan memberi arahan bagi anggota organisasi dalam mengambil keputusan dan tindakan. Pedoman organisasi terdiri atas pernyataan-pernyataan seperti citacita, misi, tujuan, strategi, kebijakan, prosedur dan aturan. Pedoman ini menyediakan informasi untuk para anggota mengenai kemana organisasi menuju, apa yang harus dilakukan, bagaimana seharusnya berpikir tentang masalah-masalah organisasi dan bagaimana solusinya serta tindakan apa yang harus dilakukan untuk mencapai keberhasilan organisasi.

Berdasarkan beberapa konsep komunikasi dan organisasi tersebut, dapat dipahami bahwa komunikasi organisasi merupakan pertunjukan dan penafsiran pesan di antara unit-unit komunikasi yang merupakan bagaian dari sebuat organisasi. Sebuah organisasi terdiri dari unit komunikasi dalam hubunganhubungan yang hierarkis antara satu dengan yang lainnya serta berfungsi dalam suatu lingkungan. Konsep suatu sistem komunikasi organisasi adalah gagasan dalam hubungan-hubungan ditentukan secara alami. Hubunganhubungan tersebut menunjukkan bahwa struktur suatu organisasi bersifat luwes dan dapat berubah sebagai respons terhadap kekuatan lingkungan internal maupun juga eksternal. Meskipun demikian, hubungan antara jabatan-jabatan berubah secara resmi berdasarkan pernyataan pejabat organisasi itu sendiri.

Perspektif interpretif (subjektif) mengasumsikan bahwa komunikasi organisasi dipandang sebagai proses pembentukan makna atas interaksi yang merupakan organisasi. Komunikasi organisasiadalah perilaku pengorganisasian yang terjadi dan bagaimana mereka terlibat dalam proses bertransaksi dan memberi makna atas apa yang terjadi.

Sifat terpenting komunikasi organisasi adalah penciptaan pesan, penafsiran dan penanganan kegiatan anggota organisasi. Bagaimana komunikasi berlangsung dalam organisasi dan apa maknanya bergantung pada konsepsi sesorang mengenai organisasi tersebut. Bila organisasi dianggap sebagai struktur atau wadah yang telah ada sebelumnya, maka komunikasi dianggap sebagai suatu substansi nyata yang mengalir ke atas, ke bawah dan ke samping dalam suatu wadah (Putnam dalam Pace dan Faules, 2010)

Farace, Monge dan Russell, mengatakan pandangan mengenai fungsi komunikasi untuk mencapai tujuan dari sistem organisasi. Fungsi-fungsi komunikasi meliputi pesan-pesan mengenai pekerjaan, pemeliharaan, motivasi, integrasi dan inovasi. Komunikasi mendukung struktur organisasi dan adaptasinya dengan lingkungan. Bila organisasi memproses informasi besar, maka proses komunikasi adalah untuk medapatkan informasi yang tepat bagi orang yang tepat dan 
pada saat yang tepat pula. Komunikasi organisasi dapat dikatakan sebagai proses mengumpulkan, memproses, menyimpan dan menyebarkan komunikasi yang memungkinkan organisasi berfungsi (Pace dan Faules, 2010).

\section{Budaya Organiasi}

Andrew Pattigrew (dalam Kusdi, 2011) mendefinisikan budaya adalah suatu sistem makna yang secara kolektif dan terbuka disepakati untuk berlaku pada suatu kelompok pada waktu tertentu. Sistem ini terdiri atas istilah-istilah, bentuk, kategori dan citra yang memberikan penafsiran terhadap situasi yang dihadapi seseorang.

Kemudian budaya menurut Edgar Schein (dalam Kusdi, 2011) adalah suatu pola asumsi-asumsi dasar yang diciptakan, ditemukan atau dibangun suatu kelompok dalam proses learning untuk mengatasi masalah adaptasi eksternal dan intergrasi internal serta telah terbukti berjalan cukup baik sehingga dianggap valid dan harus diajarkan kepada anggota-anggota baru sebagai cara yang tepat dalam memandang, berpikir dan merasa berkaitan dengan masalah-masalah tersebut.

Kalangan subjektif memandang budaya organisasi sebagai pembentukan yang membentuk realitas organisasi dan memberi makna pada anggotanya (Masmuh dalam Purworini dkk, 2014). Budaya organisasi seringkali didefinisikan sebagai perangkat norma, nilai, kepercayaan, adat, upacara, sikap dan konsep yang dianut oleh individu, kelompok, masyarakat atau organisasi. Definisi yang lebih luas menjelaskan bahwa budaya tidak hanya berupa apa yang selama ini diyakini atau melekat tetapi juga meliputi identifikasi dari seperangkat persepsi tertentu yang dibentuk oleh level individu atau kelompok.

Budaya organisasi adalah persepsi anggota organisasi mengenai nilai kunci dan konsep bersama yang membentuk citra mereka terhadap organisasi, meliputi iklim positif, pengaruh negatif, kualitas keunggulan, potensi pertumbuhan, unsur- unsur organisasi, organisasi kecil dan tidak matang dan aktif atau mendorong (Kriyantono, 2010).

Harisson dan Bayer (dalam Kusdi, 2011) mendefinisikan budaya adalah fenomena kolektif yang membentuk respon seseorang terhadap ketidakpastian dan masalah yang tidak terhindarkan dalam pengalaman manusia. Respon-respon ini terbagi menjadi dua kategori yakni (1) substansi dari budaya, sistem kepercayaan bersama dan disebut juga ideologi; (2) bentuk-bentuk budaya, entitas-entitas yang dapat diamati, termasuk tindakan dimana para anggota suatu budaya mengekspresikan, mengafirmasi dan mengkomunikasikan substansi budaya mereka satu sama lain.

Wirawan menjelaskan definisi budaya organisasi yang berisi beberapa kata kunci yang perlu untuk dijelaskan, yakni :

a. Isi budaya organisasi yaitu terdiri atas beragam jenis (artefak, nilai-nilai, norma, asumsi dan filsafat organisasi.

b. Sosialisasi yaitu budaya organisasi disosialisasikan, didifusikan dan diajarkan kepada setiap anggota organisasi baru. Isi budaya organisasi diperkenalkan dan diajarkan serta diterapkan dalam kegiatan organisasi. Bagi mereka yang merupakan anggota organisasi wajib memahami, merasa memiliki dan menerapkan dalam dirinya. Apablia anggota organisasi melanggar maka adakan diberikan sanksi.

c. Dikembangkan dalam waktu yang lama, menjelaskan bahwa budaya oganisasi dikembangkan pertama kalinya oleh pendiri organisasi. Norma, nilainilai, pola pikir, budaya dan agama dari pendiri organisasi mempengaruhi budaya organisasi (Wirawan dalam Setianti, 2012).

Menurut Sackmann, Krober dan Kluckholn menjabarkan tiga perspektif secara luas mengenai budaya yang diterapkan pada situasi organisasi dalam kepustakaan yang berhubungan dengan pengelolaan. Ketiganya meliputi : 
a. Perspektif holistik adalah memandang budaya sebagai cara-cara terpola mengenai berpikir, menggunakan perasaan dan bereaksi.

b. Perspektif variabel lebih kepada pengekspresian budaya.

c. Perspektif kognitif adalah memberi penekanan pada gagasan konsep, cetak-biru, keyakinan, nilai-nilai dan norma-norma "pengetahuan yang diorganisasikan" yang ada dalam pikiran orang-orang untuk memahami realitas (Pace dan Faules, 2010).

Sackmann (dalam Pace dan Faules, 2010) mengikuti tradisi perspektif kognitif dalam konsepnya sendiri mengenai budaya dalam organisai. Yakni menggabungkan perangkat-perangkat pembangun kognitif yang mempengaruhi persepsi, pikiran, perasaan dan tindakan dengan suatu pespektif pengembangan yang memperhatikan pembentukan dan perubahan kognisi-kognisi budaya. Kognisi sendiri menjadi pegangan dalam prosesproses interaksi sosial. Dalam pendekatan ini, esensi budaya adalah konstruksi bersama mengenai realitas sosial.

Sebuah keputusan yang penting dalam proses perubahan adalah kecepatan dimana perubahan budaya diimplementasikan dan bergantung pada kepribadian pemimpin serta tingkat ancaman dari luar. Pekerjaan seorang manajer sulit dan sangat menantang, sehingga membutuhkan penyesuaian konstan dan terus menerus untuk memastikan keselarasan budaya dengan tujuan organisasi (Bushard dkk, 2011).

Budaya dapat diuji sebagai sebuah variabel atau sebuah metafora dasar (root metapohr). Bila dipandang sebagai suatu variabel eksternal, maka budaya adalah sesuatu yang dibawa masuk ke dalam organisasi. Apabila dibatasi sebagai suatu variabel internal, maka penekanannya diletakkan pada wujud-wujud budaya (ritual, kisah-kisah dan sebagainya) yang dikembangkan dalam organisasi. Analisis metafora dasar memandang organisasi sebagai struktur pengetahuan, pola-pola simbolik bersama dan refleksi prosesproses yang tidak disadari (Smircich dan Calas dalam Pace dan Faules, 2010).

Pancanowsky dan O'Donnel-Trujillo (dalam Pace dan Faules, 2010) berpendapat bahwa ketika para anggota mewujudkan konstruk-konstruk yang relevan, praktikpraktik, ritual dan sebagainya, semua ini merupakan pencapaian kecil (miniaccomplishment) yang termasuk dalam pencapaian yang lebih besar dalam budaya organisasi Peraga dan indikator budaya dapat dimasukkan ke dalam rubik luas yang disebut simbolisme organisasi. Yang terpenting dalam konsep pemahaman budaya adalah makna simbolisme untuk anggota-anggota organisasi ketika membentuk realitas organisasi dan ketika mereka dibentuk oleh konstruk-konstruk mereka sendiri.

Budaya suatu kelompok dapat dikatakan sebagai "seperangkat pemahaman atau makna yang dimiliki bersama oleh sekelompok orang. Makna tersebut pada dasarnya diakui secara diam-diam oleh para anggotanya, jelas relevan bagi kelompok tertentu dan khusus untuk kelompok tersebut" (Louis dalam Pace dan Faules, 2010). Dengan demikian, budaya meliputi interaksi selama beberapa waktu, harapan-harapan perilaku, membentuk dan dibentuk, sifat-sifat khas yang memisahkan sebuah budaya dengan budaya lainnya dan seperangkat makna atau logika yang memungkinkan aksi kelompok.

Kegagalan proses perubahan perusahaan sebagian besar disebabkan oleh benturan budaya dan iklim. Budaya mengacu pada nilai-nilai dan tradisi yang mengakar di perusahaan. Perubahan yang berhasil dapat ditemukan dengan reframing mindset organisasi, dengan mengadopsi sistem yang holistik, jaringan dan meningkatkan komunikasi serta kerjasama. Perubahan dan adaptasi harus menjadi bagian dari nilai-nilai budaya perusahaan ( Sopow, 2007). 
Terry Deal dan Allan Kenedy (dalam Liliweri, 2014) mengatakan bahwa budaya organisasi adalah cara bagaimana kita melakukan sesuatu di sekeliling kita, budaya organisasi meliputi kebudayaan, simbol dan faktor lain yang berhubungan dengan komunikasi kepada anggota di organisasi. Ivancevich dan Matteson mengemukakan bahwa budaya organisasi dapat dipandang sebagai suatu sistem kepercayaan yang dibagi di antara anggota; kekuatan dan keluasan inti nilai yang dibagi; langkah untuk melakukan sesuatu di sekeliling organisasi; pemrogaman kolektif dari berbagai gagasan; pemahamankolektif; seperangakat kepercayaan yang dikomunikasikan melalui variasi media simbolik yang menciptakan makna dalam kehidupan manusia, seperangkat simbol, upacara dan mitos yang mengkomunikasikan nilai-nilai utama dan keyakinan bagi organisasi dan para anggota; pola-pola atau bentuk asumsi dasar yang dapat memberikan kepada anggota apa yang harus ditemui, diperoleh atau dikembangkan dalam mempelajari dan menyelesaikan masalah terhadap adaptasi eksternal dan integrasi internal ( Liliweri, 2014).

Boone dan Kurtz mendefinisikan kebudayaan sebagai pembagian kepercayaan dari suatu masyarakat, hal ini menggambarkan budaya kooperasi sebagai pola-pola perilaku yang secara umum diterima dalam suatu organisasi dan diadopsi oleh setiap generasi pekerja (Liliweri, 2014). Definisi ini sama dengan definisi tentang budaya organisasi menurut Dessler yang mendefinisikan bahwa pertukaran nilai dan harapan dari suatu perusahaan, petukaran makna dari suatu nilai yang dijadikan sebagai karakteristik organisasi (Liliweri, 2014). lan McNay (1995) mengembangkan model dimaksudkan untuk menggambarkan budaya organisasi lembaga pendidikan tinggipada dua dimensi tertentu: bentuk dan intensitas kontrol dan fokus pada kebijakan danstrategi.

Model McNay ini menampilkan empat kuadran sesuai dengan banyak jenis budaya organisasi di Universitas: (1) Enterprise, yang terdiri dari kebijakanperusahaan dan bebas pengendalian operasional, fokus pada pasar, peluang eksternaldan hubungan dengan para pemangku kepentingan; (2) Perusahaan, yang terdiri dari kebijakan yang ketat dan kontrol operasional, dominasi manajemen senior, otoritas eksekutif; (3) Collegiate, yang terdiri dari kebijakan yang bebas dan bebas kontroloperasional, desentralisasi, fokus pada kebebasan individu; (4) Birokrasi, yang terdiri dari bebas kebijakan dan pengendalian operasional yang ketat, fokus pada aturan, peraturan, dan presiden. (Lacatus, 2012: 424).

Budaya organisasi dapat mempengaruhi cara pegawai dalam bertingkah laku, cara menggambarkan pekerjaan dan cara bekerja dengan pekerja lain. Dalam setiap organisasi, budaya organisasi selalu diharapkan baik, karena budaya organisasi akan berhubungan dengan berhasil tidaknya organisasi dalam mencapai tujuannya. Robbins mengartikan budaya organisasi sebagai suatu system makna bersama yang dianut oleh anggota yang membedakan organisasi itu dengan orang lain yang merupakan seperangkat karakteristik utama yang dihargai. (Robbins, 1996).

Budaya organisasi di dalamnya terdapat budaya organisasi kuat dan budaya organisasi lemah. Robbins menjelaskan bahwa budaya organisasi yang kuat akan meningkatkan konsistensi perilaku. Suatu budya yang kuat memperlihatkan kesepakatan-kesepakatan yang tinggi di antara anggota mengenai apa yang dipertahankan oleh organisasi. Kesepakatan tersebut membina kekohesifan, kesetiaan dan komitmen organisasi.Budaya yang kuat dapat bertindak sebagai suatu pengganti untuk formalitas. Suatu budaya yang kuat mencapai tujuan akhir yang sama tanpa perlu dokumen tertulis. (Robbins, 1996).

Budaya organisasi dapat bervariasi dari lemah untuk kuat tergantung pada sejauh mana itu diterima oleh dan mempengaruhi perilaku individu. Demikian pula, sejauh mana budaya organisasi adalah sama dan 
sebangun dengan struktur penghargaan resmi organisasi dapat berkisar dari rendah ke tinggi (Bushardt, Stephen dkk, 2011).

\section{METODE PENELITIAN}

Penelitian yang dilakukan merupakan jenis penelitian deskriptif kualitatif dengan metode pengumpulan data wawancara mendalam dengan lima responden pegawai bagian humas Setda Wonogiri dengan rentang penelitian selama satu bulan September-Oktober 2015.

Dalam penelitian ini peneliti ingin mengetahui budaya organisasi pemerintah daerah, karena di era otonomi daerah dan dengan adanya masa transisi dari pimpinan maupun perombakan pegawai baru khususnya di bagian humas Setda Wonogiri, hal ini sangat menarik untuk diteliti karena apakah ada perbedaan budaya yang lama dengan yang budaya yang sekarang ini di mana zaman semakin maju dan teknologi semakin canggih. Selain itu, bagaimana budaya dikembangkan dan diinovasi untuk mencapai tujuan lembaga humas.

Pokok pertanyaan wawancara juga diadopsi dari OCAI (Organizational Culture Assement Instrument) yang dikembangan oleh Cameron dan Quinn, tujuannya adalah untuk membantu mengidentifikasi tentang budaya. Teknik analisis data dalam penelitian ini menggunakan analisis deskriptif kualitatif dengan model Miles dan Huberman dengan menggunakan koding data untuk mempermudah dalam menganalisis hasil wawancara.

\section{PEMBAHASAN}

Budaya organisasi memiliki dua sifat, yaitu budaya yang kasat mata, jelas terlihat berupa seragam, logo, ritual dan lain-lain dan budaya organisasi yang tidak terlihat berupa nilai-nilai yang ada, dipahami dan yang dilaksanakan oleh anggota organisasi. Kedua sifat budaya tersebut berfungsi sebagai identitas organisasi, sehingga orang di luar organisasi akan mudah mengenal organisasi dari identitas tersebut dan penentu arah setiap perilaku anggota organisasi. Budaya organisasi merupakan salah satu sumber daya organisasi yang menjadikan organisasi dinamis dengan karakteristik fisik maupun nonfisik yang khas berisi asumsi, nilai, norma, komitmen, kepercayaan, mendorong dan meningkatkan kinerja organisasi.

Dalam wawancara dengan lima responden yang merupakan pegawai di bagian Humas Pemda Wonogiri dapat diketahui bahwa keberadaan suatu budaya sangat penting dan telah melekat pada setiap individu bahkan di organisasi budaya telah ditanamkan dan berkembang dari masa ke masa. Birokrasi terlihat dari tugastugas operasi yang rutin melalui spesialisasi, aturan dan pengaturan yang sangat formal, tugas-tugas dikelompokkan ke dalam departemen-departemen fungsional, wewenang terpusat, rentang kendali sempit dan pengambilan keputusan mengikuti rantai komando.

Kemudian budaya di sana tidak terlepas dari kondisi sosial masyarakat terutama budaya jawanya. Kesimpulan dari tema budaya menurut kelima responden tersebut dapat dilihat bahwa budaya itu tumbuh dan melekat di organisasi, manusia, pola hidup dan perilaku dari waktu ke waktu dan budaya apa yang dibentuk, itulah yang akan menjadi budaya tinggal bagaimana budaya itu budaya yang akan berdampak positif atau negatif khususnya bagi individu maupun organisasi.

Pendapat kelima responden mengenai budaya organisasi diperkuat dengan pendapat Simirich (1983), Sackman (1991) dan Hofstede (1998) yang menyatakan bahwa aplikasi budaya yang dilakukan manusia dapat dilihat dalam kehidupan masyarakat, mulai dari kehidupan individu, kelompok komunitas, bahkan berbagai bentuk organisasi sosial maupun organisasi formal dan informal (Liliweri,2014).

Schein juga berpendapat bahwa budaya adalah suatu pola asumsi dasar yang diciptakan, ditemukan atau dikembangkan oleh kelompok tertentu 
sebagai pembelajaran untuk mengatasi masalah adaptasi eksternal dan integrasi internal yang resmi dan terlaksana dengan baik.Oleh karena itu budaya diwariskan kepada anggota-anggota baru (Umam, 2012).

Faktor budaya organisasi bisa bersumber dari internal dan eksternal. faktor-faktor internal meliputi nilai-nilai yang diantut staf; nilai dan atribut; visi dan misi organisasi; kepemimpinan. Kemudian faktor-faktor eksternal meliputi lingkungan sosial, tipe layanan yang dibutuhkan publik dan segmen (Liliweri, 2014.

Budaya bersifat selektif, karena memiliki seperangkat rambu tentang apa yang harus kita terima dan membatasi perilaku anggotanya. Perilaku yang menyimpang dari norma-norma budaya dan nilai budaya yang dilakukan oleh pimpinan dan anggota dapat dikontrol oleh budaya. Kemudian budaya juga bersifat dinamis dalam artian bahwa budaya merupakan kontrol dalam organisasi maka perilaku yang menyimpang sama halnya dengan budaya yang negatif maka hal tersbut akan dihilangkan dan apabila budaya itu baik maka budaya dipertahankan bahkan budaya bisa dikembangkan agar bisa meningkatkan kinerja. Seperti yang diungkapkan oleh Responden C sebagai berikut:

"Budaya ada kan karena faktor-faktor seperti manusia, interaksi-interaksi dan kepercayaan tadi dan terjadi secara terus menerus maka ee terbentuklah budaya, dari faktor-faktor tersebut. Kemudian budaya tersebut bisa dikembangkan lagi dengan melihat dampak dari budaya apakah budaya itu baik atau tidak. Kalau budaya yang dihasilkan buruk maka budaya itu dihilangkan tetapi jika hasilnya baik budaya dipertahankan dan dikembangkan agar bisa lebih baik lagi" (Wawancara tanggal 28 September 2015).

Kemudian yang menjadi faktor budaya organisasi di bagian humas Setda Wonogiri adalah berasal dari internal (pimpinan, anggota organisasi, interaksi atau komunikasi antar anggota, system kerja,kesepakatan-kesepakatan, administrasi birokrasi, kepercayaan, nilainilai, budaya kerja, aturan-aturan, disiplin dan etika) dan eksternal (masyarakat, lingkungan, kelompok, budaya jawa (system kepercayaan masyarakat)).

Hasil temuan yang ada dilapangan bahwa yang menjadi penekanan strategi adalah menuju stabilitas peran humas dalam memberikan pelayanan informasi yang terbuka, tepat dan akurat kepada publik; kelancaran operasional dalam melakukan kegiatan humas; membangun komitmen; dan menciptakan masyarakatyang mengerti, cerdas dan ikut bertanggungjawab kepada pemerintah.

Budaya di bagian humas termasuk budaya yang kuat karena budaya kerja di bagian humas sangat mengutamakan profesionalitas dalam bekerja, disiplin dan budaya kerja di humas yang tampak adalah administrasi birokrasinya. Keseragaman di humas yang terlihat adalah yang pertama seragam baju, di humas ada seragam baju yang di tetapkan oleh pimpiminan yaitu baju warna ungu yang dipakai setiap hari rabu dan hari kamis minggu kesekian baju yang dipakai warna hijau. Kemudian aturan protokol diseragamkan, teknik penulisan juga diseragamkan agar tampak ciri khas humasnya dan yang tidak kalah pentingnya di setiap kegiatan tim bagian humas harus ada.

Untuk menjadi instansi yang baik harus mau mendengar, melihat ke bawah dalam artian melihat kenyataan yang ada di luar instansi, mengamati perkembangan yang terjadi di luar, dan merasakan. Humas di dalam sebuah instansi berkaitan dengan pencitraan dan informasi sehingga dalam memberikan komunikasi kehumasan para praktisi humas harus bisa memberikan suatu pesan yang sama maknanya, karena hambatan dalam komunikasi itu bisa berupa persepsi-persepsi yang salah dari penerima komunikasi.

Keberadaan humas bagi organisasi sangatlah penting karena humas merupakan 
sebuah jembatan yang menghubungkan organisasi dengan publik. Oleh karena itu pekerjaan sebagai seorang praktisi humas sangatlah berat dan selalu ada pekerjaan yang rutin dilakukan bahkan diluar jam kerja sekalipun. Maka kemudian budaya seperti apa yang ditanamkan pada setiap anggota organisasi khususnya di bagian humas sangatlah berpengaruh. Seperti yang diungkapkan oleh Responden A mengenai budaya yang ada di bagian humas adalah :

"Kalau budaya yang ada di bagian humas menurut saya budayanya itu e..e budaya kerjanya itu yang paling utama. Karena saya kerja di bagian Humas sebagai Analis Media dan Jurnalis ya saya dituntut untuk bekerja secara profesional, cekatan dan jeli dengan permasalahan seputar media dan sebagai jurnalis harus menguasai komunikasi massa yang baik. Jadi saya harus lebih cepat kalau gak bisa cepat saya bisa keteteran dalam bekerja."(Wawancara pada hari Jum'at tanggal 16 September 2015 pukul 11.30).

Berdasarkan temuan di lapangan gaya manajemen yang ada di bagian humas ada planning, organizing, actuating dan controlling, kemudian untuk melakukan kegiatan manajemen ada aturan dan regulasinya sesuai dengan struktur organisasi, tata kerja, selain itu masingmasing anggota memiliki tanggungjawab terhadap pekerjaannya. Pemimpin mengelola, memanajemen agar kegiatankegitan humas berjalan dengan baik dan terarah. Tetapi ada kekurangan dalam manajemen yakni di bagian humas tidak bisa merencanakan terlebih dahulu, karena semua kegiatan humas sangat padat dan spontan, kecuali kegiatan yang sudah ditetapkan jauh hari.

Sebuah organisasi sulit untuk membentuk keseragaman tanpa adanya kepercayaan, keterbukaan dan partisipasi antaranggota, semuaitusaling berhubungan satu sama lain dan merupakan pelengkap untuk membentuk suatu komitmen. Seperti yang diungkapkan oleh Responden B, mengenai kepercayaan, keterbukaan dan partisipasi di bagian humas Wonogiri yakni:

"Semua itu sangat di butuhkan dalam kerjasama antar anggota, apalagi untuk kerjasama dalam tim. Di bagian humas ini kita semua adalah tim, dimana dalam sebuah tim itu membutuhkan komitmen yang sama dan tujuan yang sama." (Wawancara pada tanggal 26 Oktober 2015, pukul 14.45 WIB).

Pemimpin di bagian humas sangat menjunjung tinggi rasa kemanusiaan dan demokratis dengan setiap ide karyawan untuk melakukan pekerjaan di humas sesuai dengan seninya. Pimpinan juga selalu memberikan arahan yang positif kepada para karyawan dalam menyelesaikan pekerjaan dengan baik.gaya pemimpin adalah dia sebagai organizator dan bertugas untuk mengoranisir di dalam organisasi yang menjadi tanggung jawabnya dalam pemimpin para anggota-anggotanya. Pemimpin harus bisa mengelola organisasi, mengontrol dan mengarahkan bagaimana anggota bertindak. Sehingga pemimpin juga dituntut untuk bisa memahami para anggotanya seperti yang diungkapkan oleh Stephen dan Pace (1991) dalam menasehati para eksekutif yang ingin menunjukkan kepemimpinan yang lebih efektif agar "memperlakukan orang lain sebagai kawan.

Dalam temuan penelitian di lapangan menunjukkan bahwa gaya pemimpin di bagian humas adalah mengorganisir, memfasilitasi dan melakukan pendekatan dengan rasa kemanusiaan yang tinggi. Jika pimpinan dan anggota memiliki keyakinan yang sama maka organisasi dapat dikatakan akan berhasil apabila ada kesamaan visi, nilai-nilai dan keyakinan diatara anggota organisasi akan membentuk budaya yang kuat. Sebaliknya, keberagaman para anggota terhadap visi dan nilai-nilai organisasi menunjukkan lemahnya budaya organisasi (Peter dan Waterman dalam Sobirin, 2007).

Ikatan yang mempengaruhi budaya di organisasi bagian humas adanya aturan, 
kebijakan, prosedur dan harapan yang jelas di dalamnya.Hal ini yang mengikat pada tubuh organisasi pemerintah bahwa budaya yang ada di instansi pemerintah tidak terlepas dari aturan-aturan yang ada, seperti yang diungkapkan oleh Yuni tentang ikatan budaya yakni:

"Kembali lagi budaya tergantung sama pimpinannya. Ketika pemimpin itu tegas dengan budaya yang terbentuk maka ikatannya akan kuat. Tapi kalau pimpinannya tidak ya jadi kendor. Seperti aturan yang dibuat, kebijakan yang ada kalau pimpinan tidak bisa tegas maka aturan itu akan dilanggar. Kalau aturan formal ya tidak masalah karena menjadi PNS itu abdi dalemnya. Abdi dalem sendiko dawuh dengan kebijakan-kebijakan yang ada Cuma kan kalau peraturan tidak bisa dilanggar. Kemudian ketika turun kebawahkan ada kebijakan Iha kebijakan ini tergantung pimpinan luwes tidaknya, tidak kaku."(Wawancara tanggal 26 Oktober 2015).

Pendapat lain mengenai ikatan budaya pemda seperti yang dikatakan oleh Agus Sarmanto sebagai berikut:

"Karena sifatnya budaya yang ada dan melekat pada diri seseorang dan tidak diformalkan, tetapi sudah dilakukan oleh masing-masing orang. Sehingga di dalam antara budaya dengan pemerintah sebenarnya sudah ada unsur kebudayaannya. Budaya yang ada di pemerintahkan sumbernya dari aturan dan kebijakan, kemudian pada diri kita bagaimana harapan kita agar menjadi lebih baik. Justru dengan adaya aturan itu kita bekerja lebih nyaman karena dasar hukum ada, kita bekerja sesuai dengan SKPD sehingga jelas sasaran yang akan kita kerjakan. Sehingga itu akan lebih terarah, Cuma permasalahannya pada aturan yang baru kita harus nunggu sehingga yang cepat menjadi terlambat. Intinya dengan adanya aturan semua lebih nyaman, lebih terukur dan maksimal."
(Wawancara tanggal 16 Oktober 2015).

Bagi humas komunikasi kepada Publik menjadi urutan yang pertama dalam tujuan humas, karena humas bertujuan untuk memberikan informasi-informasi menyangkut instansi dan kegiatan humas bagi masyarakat. Sehingga dalam hal ini humas perlu memikirkan bentuk komunikasi yang seperti apa untuk di suguhkan kepada Publik seperti menggunakan media komunikasi berbetuk website. Seperti yang diungkapkan oleh Responden A mengenai komunikasi kehumasan adalah :

"Sebagai praktisi humas, humas dituntut untuk dapat memberikan pelayanan informasi kepada masyarakat. Untuk itu humas harus menyediakan platform agar masyarakat dapat berinteraksi secara langsung dengan pemerintah melalui humas. Saat ini Humas Wonogiri sudah memberikan layanan kepada masyarakat berupa Website Humas Wonogiri melalui www.humas. wonogirikab.go.id melalui website tersebut masyarakat dapat memperoleh informasi mengenai kegiatan humas, berita terbaru seputar Wonogiri dan informasi lengkap lainnya mengenai Kabupaten Wonogiri. Sehingga melalui website tersebut masyarakat puas dengan informasi dan masyarakat bisa percaya dengan pemerintah karena informasi yang diberikan melalui sumber yang terpercaya. Menjadi instansi yang baik itu ketika kita mau mendengar."(Wawancara pada tanggal 16 September 2015, pukul 12.00 WIB).

\section{E. KESIMPULAN}

Bagi organisasi pemerintah seperti Pemda, budaya organisasi termasuk ke dalam model "Hierarchy Culture" atau bisa disebut juga "Budaya Birokrasi" yang artinya bahwa dalam organisasi tersebut memiliki struktur yang kuat, bersifat formal, memiliki prosedur, aturan, kebijakan, undangundang, control, sanksi dan memiliki strategi untuk mencapai stabilitas, efisiensi serta kemungkinan meramalkan. 
Humas Wonogiri melakukan kegiatan komunikasi kehumasan melalui rapat-rapat koordinasi,WebsiteHumas, Publikasikeliling, layanan aduan masyarakat "Pakdimas" dan siaran melalui radio lokal Wonogiri (RSPD). Temuan dalam hasil wawancara menyatakan bahwa dalam komunikasi ada dua arus besar dalam instansi pemerintah yakni media dan masyarakat. Kenyataan yang di lapangan, instansi pemerintah tidak jarang mendapat kritik pedas dari media dan surauan masyarakat yang tidak mempercayai kinerja pemerintah.

Humas Wonogiri melakukan kegiatan komunikasi kehumasan melalui rapatrapat koordinasi, Website Humas, Publikasi keliling, layanan aduan masyarakat "Pakdimas" dan siaran melalui radio lokal Wonogiri (RSPD).

Tipe budaya organisasi di bagian humas Pemda Wonogiri adalah sebagai berikut :

1. Dominant Atribut: Undang-Undang, Kebijakan, Peraturan dan Sasaran.

2. Bonding: Pimpinan, Aturan, Prosedur dan Kebijakan.

\section{Leader Style: Mengorganisir, Memfasilitasi dan Pendekatan Kemanusiaan.}

4. Strategic Emphases: Kelancaran Operasional, Komitmen Bersama dan Stabilitas Peran Humas.

Faktor yang mempengaruhi budaya organisasi di bagian humas Wonogiri adalah faktor internal dan eksternal.faktor internal berasal dari dalam organisasi seperti pimpinan, sistem kerja, interaksi sesama anggota organisasi, kesepakatankesepakatan, etika dan nilai yang dianut individu. Kemudian faktor eksternal berupa keadaan sosial masyarakat dan sistem kepercayaan masyarakat.

Komitmen semua pegawai humas adalah mengabdi pada instansi, masyarakat, membangun masyarakat yang sejahtera dan berusaha melaksanakan semua kegiatan humas dengan professional khususnya dalam membangun komunikasi berupa informasi yang terbuka kepada Publik.
Kemudian untuk pengambilan resiko hanya dua responden yang berani mengambil resiko, karena menurut mereka resiko itu memang ada yang penting bekerja dengan baik dan selama ada impian dan tetap optimis resiko bisa dilalui dengan mudah.

Budaya di humas sangat dinamis, abstrak dan kemungkinan untuk berinovasi karena budaya dibentuk oleh pimpinan sehinga budaya bisa berubah tergantung pimpinan ingin membentuk budaya yang seperti apa. Pimpinan humas Wonogiri menerapkan pola kerja secara formal, normatif dan aturan yang sesuai, kemudian budaya kerja di humas disiplin, ada sanksinya, pekerjaan dilakukan dengan seni sehingga dalam bekerja ada urutannya yaitu kerjakan, tindak lanjuti dan mengembangkan seninya, kreaktivitasnya.

Yangmenjadihambatan dalamorganisasi adalah adanya hambatan struktural pada penempatan kepegawaian yang kurang pas dengan kriteria di humas, aturan yang belum ada sehingga kerja humas tidak bisa dilakukan dengan cepat, kerja humas tidak mengenal waktu sehingga tingkat stress bisa meningkat, jurang komunikasi antara pemerintah dengan masyarakat dan media, membangun komitmen yang baru ketika ada pimpinan baru, masyarakat yang sulit diajak bekerjasama dengan pemerintah dan budaya yang tidak produktif seperti masih ada rasa sungkan "perkewuh".

Permasalahan yang lain di lingkungan pemerintah seperti di Pemda Wonogiri, ditemukan bahwa di bagian humas dengan bagian lainnya memiliki masalah dalam komunikasi antar bagian organisasi. Contohnya ketika ada pengangkatan Kepala Bagian dalam organisasi ternyata organisasi yang lain jarang yang mengetahuinya dalam artian bahwa yang menjabat sebagai Kepala Bagian di Humas, di bagian Kesejahteraan Masyarakat tidak mengenal dan mereka tidak tahu siapa yang menjabat sebagai Kepala Bagian sekarang. Artinya organisasi di bagian yang satu dengan yang lainnya kurang adanya interaksi atau komunikasi yang terjadi di dalam organisasi Pemda. 
Adanya permasalahan masyarakat yang kontra dengan pemerintah seharusnya dapat dilakukan penelitian tentang survey kepuasan masyarakat atau analisis resepsi masyarakat terhadap kinerja pemda atau dengan menggunakan analisis media dengan membandingkan Pemda yang satu dengan Pemda yang lainnya mengenai media yang digunakan sebagai komunikasi kehumasan.

\section{DAFTAR PUSTAKA}

\section{Buku:}

Ardianto, Elvinaro. 2011. Handbook of Public Relations : Pengantar Komprehensif. Bandung: Simbiosa Rekatana Media

Kusdi. 2011. Budaya Organisasi : Teori, Penelitian dan Praktik. Jakarta: Salemba Empat.

Liliweri, Alo. 2014. Sosiologi dan Komunikasi Organisasi. Jakarta: PT Bumi Aksara.

Mulyana, Deddy. 2010.

Pace, R. Wayne, Don F. Faules. 2010. Komunikasi Organisasi: Strategi Meningkatkan Kinerja Perusahaan. Editor : Deddy Mulyana. Bandung : Remaja Rosdakarya.

Robbins, Stephen. 1996. Perilaku Organisasi, Konsep, Kontroversi dan Aplikasi. Alih Bahasa : Hadyana Pujatmaka. Edisi keenam. Jakarta : PT. Bhuana Ilmu Populer.

Sobirin, Achmad. 2007. Budaya Organisasi: Pengertian, Makna dan Aplikasinya dalam Kehidupan Organisasi. Yogyakarta: UPP-STIM YKPN.

Umam, Khaerul. 2012. Perilaku Organisasional. Yogyakarta: C.V Andi

\section{Non Buku :}

Bushardt, Stephen. Glascoff, David. Doty, Harold. 2011. Organizational Culture, Formal Reward Structure, And Effective Strategy Implementation: A Conceptual Model. Dalam jurnal ProQuest Vol 15 No. 57-70. United States : Jordan Whitney Enterprises, Inc.

Hilman, Haim. Siam, Mohammed. 2014. The Influence of Organizational Structure and Organization Cukture on the Organizational Performance of Higher Educational Institutions : The Moderating Role Of Strategy Communication. Dalam jurnal ProQuest Vol 10 No. 142-154. Canada: Asian Social Science.

Lacatus, Maria. 2013. Fifth edition International Conference EDU-WORLD 2012 Education Facing Contemporary World: Organizational Culture in Contemporary University. Procedia-Social and Behavioral Sciences. Vol. 76, 2013 :421-425. Elsevier Ltd.

Mulyana, Deddy. 2001. Merancang Peran Baru Humas dalam pengembangan Otonomi Daerah. Mediator, Vol. 2, No. 1, 2001.

Purworini, Dian. Sutarso, Joko. Haryanti, Yanti. 2014. Model Penggunaan Media Sosial Untuk Meningkatkan Partisipasi Publik Di Era Otonomi Daerah. Surakarta: LPPM.

Setiati, Yanti. 2012. Budaya Organisasi dan Iklim Komunikasi. Bandung : Universitas Padjajaran.

Suharyanti. Widiastuti, Tuti. Kania, Dessy. 2012. Reformasi Birokrasi Pemerintah dan Penerapan Excellence Theory. Jakarta : Universitas Bakrie.

Sopow, Eli. 2007. The Impact Of Culture And Climate On Change. Dalam jurnal ProQuest Vol 6 No. 20-23. Canada: Melchrum Publishing 